\title{
Editorial \\ La creatividad y la virtualidad en la Educación Superior
}

\author{
Henry Acuña Barrantes ${ }^{2}$
}

Las prácticas docentes que estimulan una mayor aportación de los estudiantes, da lugar a un trabajo motivador que incita el pensamiento creativo, memorístico e innovador, el cual asimismo potencia su autonomía y facilita el aprendizaje profesional, y esto es precisamente lo que se busca en la actualidad con la modalidad virtual en la educación. Sin embargo, la crítica a los modelos tradicionales donde, por ejemplo, la idea de asumir que una metodología educativa sirve a todo individuo, podría ser tan paradójico como plantear que todos los estudiantes deben estudiar solamente en la jornada diurna para captar mejor una enseñanza.

Por definición, cada persona es única; sus preferencias, gustos y pasiones son particulares; por consiguiente, es erróneo pretender que cada uno se ajuste a un solo patrón de formación, lo que lleva a desperdiciar competencias que de haberse identificado y cultivado de manera apropiada y temprana, pudiesen crear cantidades enormes de valor para el individuo y para su entorno.

Habitualmente la tarea del docente ha sido la de transmitir una sucesión de conocimientos avalados por alguna institución educativa que determina cuáles deben ser los temas por dominar trasversalmente para todo estudiante según su edad y conocimiento adquirido previamente. En este paso, quienes tienen la idoneidad de ajustarse al sistema logran mantenerse e incluso sobresalir, y quienes no lo pueden lograr, por lo general son catalogados como personas con desempeños académicos bajos y hasta relegados.

En la actualidad, el profesor prepara y desarrolla su clase para posteriormente evaluar lo aprendido; no obstante, las prelaciones se modificaron. Ahora los estudiantes trabajan los temas en su propio tiempo con ayuda de las TIC, el material de estudio es elaborado y actualizado regularmente en las plataformas de las Instituciones de Educación que imparten modalidades virtuales en búsqueda de determinar si el estudiante puede trabajarlas autónomamente, si encuentra dificultades, se cuenta con el apoyo del docente-tutor con sus clases programadas mediante videoconferencias.

Los resultados ya se evidencian en la educación virtual: estudiantes que tenían dificultades, una vez alcanzan la habilidades, logran cumplir sus tareas con mayor rapidez aligerando su propio conocimiento, de la mano del docente-tutor, lo cual garantiza retroalimentación y respuesta oportuna del estudiante en su formación y aprendizaje; a su vez, cada individuo se toma y administra el tiempo que requiera para garantizar el dominio del material. Estudios

${ }^{1}$ Economista y Especialista en Alta Gerencia, Universidad Militar Nueva Granada (UMNG). Posgrado en Global Marketing, Universitat de Girona, España; Máster en Comercio Exterior Marketing Internacional; Doctorando en Global Ethics, Religions and International Business (DIB), Escuela Española de Negocios Internacionales; Docente de la misma institución; Profesional Especializado, Faedis; miembro Grupo de Liderazgo, UMNG; Colciencias. Correos: henry.acuna@unimilitar.edu.co, hacuna@reingexeeni.edu.es 
indican que un estudiante en modalidad virtual debe tener un alto grado de creatividad y memoria visual (Acuña, 2016); por ello, esta modalidad no es para todos.

\section{Modalidad virtual en la educación}

Existiendo la modalidad de educación virtual ya para la formación secundaria y superior, plataformas y software amigables, los maestros podrán actualizar y crear ágilmente contenidos digitales de calidad, dice el investigador Borrero (2014):

¿Habrá llegado la hora de reconstruir el modelo educativo? ¿Por qué no pensar en el docente, no como un transmisor de contenidos, sino como un verdadero mentor, alguien que pueda acompañar de manera individual a sus estudiantes para diseñar un plan académico que garantice el aprovechamiento de sus creatividades y virtudes? [...] Los recursos digitales facilitan la gestión de transmisión del conocimiento, y el docente podrá enfocar su labor en la interpretación de diagnósticos y el diseño de planes de formación ("Un nuevo modelo educativo que rescate la creatividad").

Por otra parte, tal como dice Saturnino de la Torre, "[...] el siglo XXI será llamado a ser el siglo del conocimiento, la creatividad e innovación"; los estudiantes aprenden construyendo e innovando, y la modalidad virtual es un excelente método educativo, para que estos individuos apoyados en todo lo que les ofrece el entorno, se sientan motivados al tener un papel activo en la planificación de su propio aprendizaje.

Por consiguiente $y$ en esa medida, la modalidad virtual no sustituirá a corto plazo la modalidad presencial tradicional, aunque sí la ha permeado y le ha restado un porcentaje importante de estudiantes, dado que la sociedad para capacitarse requiere de estas particularidades de tiempos y espacios flexibles para su formación.
Este volumen 9 No. 2, de la Revista Academia y Virtualidad, pone a disposición artículos de destacados investigadores nacionales e internacionales. El contenido expone y continúa los lineamientos y orientaciones establecidos por la Dirección de la Revista, en cabeza del doctor Felipe Riaño Pérez, Decano de la Facultad de Estudios a Distancia, del Comité Editorial y del Comité Científico.

A continuación se presentan nueve artículos de investigación, reflexión y revisión, resultados de investigación. Se destacan los artículos que muestran un trabajo basado en las diferentes problemáticas educativas, en particular aquellas que involucran las TIC y todos aquellos aspectos que, en una u otra medida, cimientan la educación virtual. En el primer documento, las investigadoras Díaz, Llamas y López, de nacionalidad chilena la primera y españolas respectivamente, de la Universidad Internacional de la Rioja, presentan el artículo de investigación científica titulado "Relación entre creatividad, inteligencias múltiples y rendimiento académico en alumnos de enseñanza media técnico profesional del área gráfica. Programa de intervención neuropsicológico utilizando las TIC", cuyo estudio tiene como objetivo establecer si existe relación entre la creatividad, las inteligencias múltiples y el rendimiento académico.

Por otro lado, los profesores Huertas y Villamil, en su trabajo de investigación "Características de la investigación formativa en los programas de ingeniería, a distancia y virtual, en Bogotá", se enfocan en establecer los hallazgos aportando información sobre los procesos investigativos y las tendencias positivas a partir de la investigación formativa en los programas de Ingeniería en Bogotá. Asimismo, los resultados contribuyen con evidencias sobre los sentidos y significados didácticos que tiene la investigación formativa en el ámbito pedagógico del aprendizaje para eventuales decisiones en cuanto a la solución de problemas, por ejemplo, el ABP, entre otros contextos prácticos y/o metodológicos.

A continuación, los investigadores Cárdenas 
y Boude presentan un artículo de reflexión titulado "Cómo empoderar a las instituciones de educación básica en la incorporación de las TIC", donde los principales resultados indican que es posible observar cómo la capacitación y el fortalecimiento de las competencias TIC, apoyadas de diagnósticos y reflexiones de manera crítica sobre el rol docente, permitirán que los docentes fomenten en los estudiantes el uso de estas herramientas con actitudes y competencias que transformarán el ámbito educativo. Luego, la doctora Cánchica de Medina de la Universidad Nacional Experimental Francisco de Miranda, de Venezuela, en su trabajo de investigación "Modelo Gavilán para el desarrollo de competencias en el manejo de información a través de Google Drive. Una experiencia innovadora", muestra que se ha aprovechado la potencialidad comunicativa e interactiva de Google Drive, al realizar actividades síncronas y asíncronas entre los compañeros de cada equipo, siguiendo un conjunto de pasos y subpasos que orientan el alcance de competencias en el manejo de información (CMI) para la construcción de conocimientos emergentes a partir de procesos investigativos en la web.

A su vez, los ingenieros Infante, Bautista y Berdugo presentan un resultado de investigación sobre la "Emulación del Videojuego 'Pong', mediante robots móviles con herramientas LEGO ${ }^{\circledR}$ MindStorms NXT 2.0"; resaltan un trabajo innovador que describe la elaboración e implementación de dos robots móviles, utilizando LEGO ${ }^{\circledR}$ MindStorms NXT 2.0 y la aplicación de la plataforma LabVIEW, para reproducir, de forma física, el video juego Pong ${ }^{\circledR}$, con el fin de implementar las acciones de bloquear y lanzar una pelota en fútbol robótico. Con respecto al trabajo "Aprovechamiento de residuos orgánicos agrícolas y forestales en Iberoamérica", de Chávez y Rodríguez, la investigación presenta una revisión de la gestión de los residuos sólidos orgánicos en zonas agrícolas y forestales así como sus alternativas de reutilización, que han sido implementadas en diferentes países, lo que ha forjado alternativas de adaptación con respecto a los cambios que se presentan.

Por otra parte, Ogliastri y García presentan un resultado de investigación titulado "Contexto de aplicación de las Normas Internacionales de Información Financiera (NIIF)". Este estudio indica que es posible que a mediano plazo, algunas Pymes en Colombia, tengan que optar por algunas opciones de capitalización a través de diferentes opciones de combinación de negocios, debido a que se estima un incremento de las inversiones en Colombia por parte de los países con los cuales Colombia sostiene un Tratado de Libre Comercio y una rápida capitalización de las Pymes nacionales, debido a los incentivos fiscales que otorga la Ley 1429 del 2010 por cinco años, a partir de la creación de la empresa.

Finalmente, los docentes García y Dueñas presentan su trabajo de investigación "Los aspectos cualitativos en las Pymes y los nuevos retos gerenciales frente a las NIIF", cuyo propósito general es presentar los patrones que todo gerente que lidera una empresa debe asumir para el correcto manejo contable y financiero, con respecto a la entrada en vigencia de la nueva normatividad internacional.

Ahora bien, en nombre de la Revista Academia y Virtualidad, agradecemos a todos los autores de los artículos, a los grupos y redes de investigación, a los árbitros, a los miembros del Comité Editorial, del Comité Científico, y al equipo de traductores, revisores metodológicos, revisores técnicos y correctores de estilo, por contribuir al excelente nivel académico y científico de nuestra publicación. También informar a nuestros lectores que la revista fue indizada en este semestre por las bases bibliográficas ProQuest y Clase, lo que motiva a continuar por la línea y horizonte trazado por el director y el comité editorial y científico.

\section{Revista Academia y Virtualidad Julio-Diciembre de 2016}




\title{
Editorial \\ Creativity and virtual reality in Higher Education
}

\author{
Henry Acuña Barrantes
}

Teaching practices encouraging students' output to motivate their work may trigger their creative, memoristic and innovative thinking, which also enhances autonomy and eases their professional learning, and this is exactly what is intended currently by using the virtual mode in the educational realm. However, criticism against traditional models, e.g. where the idea that an homogeneous educational methodology works for all the people could be as paradoxical as assuming that every student should study only on daily time to learn better.

By definition, each person is unique; his perceptions, likes and passions are singular, therefore, it is wrong to assume that each individual might fit upon just one single training pattern, leading to waste skills, something that appropriately and early identified and cultivated could produce huge value to the individuals and their own environment. Usually the teaching task has been developed to transfer a series of knowledge guaranteed by an educational institution that establishes the topics to be learnt by all the students by age and knowledge level. In this scenario, those who are able to stay to the system might be successfully kept or may excel, but those who cannot achieve usually are considered as people with low academic performance and even displaced.

Currently, the teacher prepares and develops classes and sessions to evaluate what they have learned. However, the priorities have been changed, since now students work by themselves topics in their own times using ICTs. The educational materials often are developed and updated upon platforms of educational institutions providing virtual methods to determine whether the student may work on them by himself, or may have issues, or supported by teacher-tutor by videoconferencing classes.

Results are already evident in virtual education: students with difficulties, once they may master certain skills, they manage to fulfill their tasks faster to speed their own knowledge accompanied by the teacher-tutor, ensuring timely feedback and response to their training and learning processes; in turn, each individual is given the time required to ensure mastery of the educational materials. Some studies indicate that a student in virtual mode must have a high degree of creativity and visual memory (Acuña, 2016); therefore, such approach is not for everyone.

\section{Education and virtual mode}

Since there is a mode virtual education for secondary and higher education through platforms and friendly software, teachers can swiftly update and create high-quality digital contents. In this regard, the researcher Borrero says (2014):

[...] Will there be time to rebuild the educational model? Why not think about the teacher, not just as a content transmitter but a true mentor, someone who can accompany their students by himself to design an academic plan that ensures their creative use and virtues? [...] The digital resources are easing knowledge transmission management, and the teacher can focus his task upon understanding diagnostics and design of training plans ("A new model of education to rescue creativity".)

Moreover, as Saturnino de La Torre says "[...] the twenty-first century will be called the century of knowledge, creativity and 
innovation," since students learn by building and innovating, and the virtual mode is an excellent educational method, so these individuals supported by everything in the scenario may be motivated to play an active role by planning their own learning.

Therefore and to that extent the virtual mode will not replace the traditional focus in the short-term, although it has invaded and taken away a relevant percentage of students, since society for training demands those special times and flexible spaces for training.

This volume 9 No. 2 of the Revista Academia y Virtualidad offers you some papers by leading national and international researchers. Our contents offer and continue with guidelines established by the Board of the Journal, headed by Dr. Felipe Riaño Pérez, Dean of the Faculty of Distance Learning, the Editorial Board and the Scientific Committee.

The following nine papers of research, reflection and review, and research results highlight topics and issues related to different educational problems, particularly those involving ICTs and all of those issues that anyway underpin virtual education. In the first document, researchers Diaz, Llamas and Lopez, from Universidad Internacional de La Rioja, present a scientific research article entitled "Relation among creativity, multiple intelligence and academic performance of vocational technical schools of graphics. A neuropsychological program using ICTs", which aims to establish a presumable relationship among creativity, multiple intelligences and academic performance.

On the other hand, professors Huertas and Villamil in their paper, "Research training features: distance \& virtual Engineering programs in Bogota," focus to set findings providing information about research processes and positive trends by research training of Engineering programs in Bogota. The results also evidence relevant didactic senses and meanings that research training has into the learning field for possible measures regarding troubleshooting, e.g. the PBL approach among other practical and/or methodological contexts.

Then researchers Cardenas and Boude provide a reflection article, entitled "Empowering Basic Education Institutions to incorporate ICTs", where the main results show it is possible that training and strengthening ICT skills (supported by diagnostics and critical reflections about the teaching role) let teachers encourage students to use those tools with attitudes and skills that may transform education. Then Dr. Canchica de Medina from Universidad Nacional Experimental Francisco de Miranda, in her research, "Gavilan Model to develop skills in information management by Google Drive. An innovative experience," shows the communicative and interactive potential of Google Drive, to perform synchronous and asynchronous activities among peers of each team, following a set of steps and sub-steps that guide the scope of competence in managing information (CMI) to build knowledge resulting from research processes in the web.

In turn, engineers Infante, Bautista and Berdugo present a research result about "Videogame emulator 'Pong', using mobile robots with tools LEGO ${ }^{\circledR}$ MindStorms NXT 2.0." They highlight an innovative work describing the development and implementation of two mobile robots using LEGO ${ }^{\circledR}$ MindStorms NXT 2.0 under application of the LabVIEW platform to play physically the video game Pong ${ }^{\circledR}$ in order to implement actions (block and throw a ball) in robotic-soccer. Regarding the research "Harnessing agricultural and forestry organic waste in Latin America," Chavez and Rodriguez present a review of the management of solid organic waste in agricultural and forest areas as well as alternatives to reuse, which have been implemented in different countries, by building adaptation options in relation to the changes that occur. 
Moreover, Ogliastri and Garcia offer a research result, entitled "Implementation context for IFRS." This analysis indicates it is possible that some Colombian SMBs in the medium term have to adopt some capitalization options through different business combination options because an increasing investment has been estimated by countries with which Colombia has a Free Trade Agreement, besides a swift capitalization of domestic SMBs due to tax incentives granted by Act 1429 of 2010 for five years from the creation of the business. Finally, professors Garcia and Dueñas give their research, "Qualitative issues by SMBs and new management challenges facing the IFRS," whose main goal is to report the patterns that every manager who leads a business must take for an appropriate accounting and financial management regarding the new international standards in force.

Now, on behalf of Revista Academia y Virtualidad, we thank all the authors of papers, research teams and networks, referees, members of the Editorial Board, the Scientific Committee, and the team of translators and methodological and technical proofreaders for their contribution to get a better academic and scientific level of our journal. Also we inform our readers that our publication has been indexed this semester in databases ProQuest and Class, something which motivates us to continue working given by Director, the Editorial Board and the Scientific Committee.

Revista Academia y Virtualidad July-December 2016 


\section{Editorial \\ A criatividade e a virtualidade na Educação Superior}

Henry Acuña Barrantes

As práticas docentes que estimulam uma maior aportarão dos estudantes, provocam um trabalho motivador incitante do pensamento criativo, de memorização e inovador, que por sua vez otimiza sua autonomia facilitando a aprendizagem profissional, isso é o que neste momento se procura na modalidade virtual aplicada no campo educativo. No entanto, a crítica aos modelos tradicionais onde, por exemplo, a ideia de assumir uma metodologia educativa serve a todo indivíduo, poderia virar tão paradoxal quanto supor que todos os estudantes deveriam estudar somente na jornada diurna para segurar melhor seu ensino. Manifestamente cada pessoa é única; suas preferências, gostos, e paixões são peculiares, consequentemente, é errada a pretensão que cada um se acomodar a um só padrão de formação, isso só levaria a dilapidar competências que de terem sido identificadas e cultivadas de jeito adequado e em tempo, poderiam criar quantidades enormes de valor para o indivíduo e o seu redor. Costumeiramente, a tarefa do docente tem sido de transmitir uma sucessão de conhecimentos avaliados por alguma instituição educativa que determina quais devem ser os temas a dominar transversalmente para todo estudante segundo sua idade e conhecimentos adquiridos. Nessa dinâmica, aqueles que têm a idoneidade de corresponder ao sistema conseguem se manter e até ser notáveis, e aqueles que não o conseguem, normalmente são aludidos como pessoas com desempenhos académicos baixos e até banidos.

$\mathrm{Na}$ época atual, o professor prepara e desenvolve sua aula para em seguida avaliar o aprendido; no entanto, as prelações foram trocadas. Agora os estudantes trabalham seus temas no seu próprio tempo com ajuda das TIC, o material de estudo é elaborado e atualizado regularmente nas plataformas das instituições de educação que ofertam modalidades virtuais na procura de determinar se o estudante pode trabalha-las de maneira autónoma, se depara com dificuldades, ou conta com suporte do docente-tutor com suas aulas programadas através de videoconferências.

Os resultados já são evidenciados na educação virtual, estudantes com dificuldades, quando alcançarem certas habilidades, conseguem executar suas tarefas com maior rapidez agilizando seu próprio conhecimento, da mão do docente-tutor, o que assegura a realimentação e resposta em tempo do estudante na sua formação e aprendizagem, por sua vez, cada indivíduo toma e administra o tempo do que precisa para assegurar o domínio do material. Estudos apontam que um estudante em modalidade virtual deve ter um alto grau de criatividade e memória virtual (Acuña 2016); por isso essa modalidade não é para todos.

\section{Modalidade virtual na educação}

Existindo já a modalidade de educação virtual para a formação secundária e superior, por meio de plataformas e software amigáveis, os mestres poderão atualizar e criar velozmente conteúdos digitais de qualidade, disse o pesquisador Borrero (2014):

Será chegada a hora de reconstruir o modelo educativo? Por que não pensar no docente, já não como um transmissor de conteúdo, senão enquanto um verdadeiro mentor, alguém que possa acompanhar de jeito individual aos seus estudantes para desenhar um plano académico que assegure o aproveitamento de suas criatividades e virtudes? Os recursos digitais facilitam a gestão de transmissão do 
conhecimento, e o docente poderá focalizar sua labor na interpretação de diagnósticos e no desenho de planos de formação. ("Um novo modelo educativo que socorrer a criatividade").

No entanto como diz Saturnino De La Torre, o século XXI será chamado a ser o século do conhecimento, a criatividade e a inovação, os estudantes aprendem construindo e inovando, e a modalidade virtual é um ótimo método educativo, para que esses indivíduos baseados em todo o que lhes oferece seu redor, se sentirem motivados ao atingir um papel ativo na planificação de sua própria aprendizagem. Consequentemente e nessa medida, a modalidade virtual não vai trocar prontamente a modalidade presencial tradicional, embora a tenha sim impregnado e desviado uma porcentagem importante de estudantes, uma vez que a sociedade para se preparar requer destas particularidades de tempos e espaços moldáveis para sua formação.

Este volumem 9 No. 2, da Revista Academia y Virtualidad, põe à disposição artigos de pesquisadores de destaque nacional e internacional. O conteúdo expõe e continua com os lineamentos e orientações estabelecidas pela Direção da Revista, em cabeça do doutor Felipe Riaño Pérez, Decano da Faculdade de Estudos a Distância, do Comité Editorial y do Comité Científico.

Em seguida apresentam-se nove artigos de pesquisa, reflexão e revisão, resultados de pesquisa. Destacam-se os artigos que mostram um trabalho baseado nas diferentes problemáticas educativas, nomeadamente aquelas que involucram as TIC e todos aqueles aspetos que, de qualquer jeito, cimentam a educação virtual. No primeiro documento, os pesquisadores Díaz, Llamas y López, da Universidade Internacional de La Rioja, apresentam o artigo de investigação científica titulada "Relação entre criatividade, inteligências múltiplas e produtividade académica em alunos de ensino médio técnico professional da área gráfica. Programa de intervenção neuropsicológica utilizando as TIC", cujo estudo tem como objetivo estabelecer se existe uma relação entre a criatividade, as inteligências múltiplas e a produtividade académica.

Deoutraparte, os professores Huertase Villamil, no seu trabalho de pesquisa "Caraterísticas da pesquisa formativa nos programas de engenharia, a distância e virtual, em Bogotá" focalizam-se no estabelecimento de achados aportando informação sobre os processos investigativos $\mathrm{e}$ as tendências positivas a partir da pesquisa formativa nos programas de Engenharia de Bogotá. Do mesmo jeito, os resultados contribuem com evidências sobre os sentidos e significados didáticos que tem a pesquisa formativa no âmbito pedagógico da aprendizagem para eventuais decisões no que tem a ver com a solução de problemas, por exemplo, o ABP, entre outros cenários práticos e/ou metodológicos.

Em seguida, os pesquisadores Cárdenas y Boude, apresentam um artigo de reflexão intitulado "Como acrescentar o poder das instituições de educação básica na incorporação das TIC", onde os principais resultados indicam que é possível enxergar como a capacitação e o fortalecimento das competências TIC, sustentadas de diagnósticos, e reflexões de jeito crítico sobre o papel docente, permitirão que docentes fomentem nos seus estudantes o emprego destas ferramentas com atitudes e competências que transformarão o âmbito educativo. A doutora Cánchica de Medina da Universidade Nacional Experimental "Francisco De Miranda" de Venezuela, no seu trabalho de pesquisa "Modelo Gavião para o desenvolvimento de competências na manipulação de informação através de Google drive. Uma experiência inovadora", mostra o potencial comunicativo e interativo de Google drive, ao realizar atividades síncronas e assíncronas entre os parceiros de cada equipe, seguindo um conjunto de passos e sob passos que têm direcionado a consecução de competências na manipulação de informação (CMI) para a construção de conhecimentos 
emergentes desde processos investigativos na web.

Por sua vez, os engenheiros Infante, Bautista y Berdugo, apresentam o resultado da pesquisa sobre a 'Emulação do videojogo 'Pong', usando Robôs móveis com ferramentas Lego MindStorms NXT 2.0". Eles salientam um trabalho inovador que descreve a elaboração e aplicação de dois robôs móveis, utilizando LEGO® MindStorms NXT 2.0 e a aplicação da plataforma LabVIEW, para reproduzir, de jeito físico, o videojogo Pong ${ }^{\circledR}$, com o intuito de aplicar as ações de bloqueio e lançamento de uma pelota em futebol robótico. No tocante ao trabalho "Aproveitamento de resíduos orgânicos agrícolas e florestais em Ibero-américa", de Chávez e Rodriguez, a pesquisa apresenta uma revisão da gestão dos resíduos sólidos orgânicos de zonas agrícolas e florestais; tanto quanto suas alternativas de reuso, que já foram aplicadas em diferentes países, criando alternativas de adaptação sobre as variações que se apresentam.

De outro lado, Ogliastri y García, apresentam um resultado de pesquisa nomeado "Contexto de Aplicação das Normas Internacionais de Informação Financeira (NIIF)"'. Este estudo aponta que é possível que no mediano prazo, algumas Pymes na Colômbia, terão de optar por diferentes ofertas de combinação de negócios, em razão a que se estima um incremento das inversões na Colômbia de parte dos países com os quais a Colômbia mantem um Tratado de libre comércio e uma rápida capitalização das Pymes nacionais, graças aos incentivos fiscais que lhe confere a lei 1429 de 2010 por cinco anos, a partir da criação da empresa.

Afinal, os docentes García y Dueñas apresentam seu trabalho de pesquisa "Os aspectos qualitativos das Pymes e os novos retos gerenciais diante das NIIF", cujo propósito geral é apresentar os padrões que todo gerente que lidera uma empresa deve assumir para a correta gestão de contadoria e financeira, no tocante ao começo da vigência da nova normatividade internacional.

Entretanto, em nome da Revista Academia y
Virtualidad, agradecemos a todos os autores dos artigos, aos grupos e redes de pesquisa, aos árbitros, aos membros do Comité Editorial, do Comité Científico, e à equipe de tradutores, revisores metodológicos, revisores técnicos e corretores de estilo, pela contribuição ao ótimo nível académico e científico de nossa publicação. Também informar a nossos leitores que a revista foi indexada neste semestre pelas bases bibliográficas ProQuest e Clase, o que incentiva a continuar pela linha e horizonte traçado pelo diretor e o comité editorial e científico.
Revista Academia y Virtualidad Julho-Dezembro 2016 